\title{
Employees' psychological characteristics and sustainable leadership in firms with high and low entrepreneurial orientation
}

\author{
Susanne Durst ${ }^{1}$, Farzana Chowdhury ${ }^{2}$, Andrés Davila ${ }^{3}$, Sascha Kraus ${ }^{4}$, Cheng-Feng Cheng ${ }^{5}$ \\ ${ }^{1}$ Tallinn University of Technology, Department of Business Administration, Ehitajate tee 5, 19086 Tallinn, Estonia, susanne.durst@taltech.ee \\ ${ }^{2}$ Durham University, Department of Management and Marketing, Mill Hill Lane, Durham DH1 3LB, United Kingdom, farzana.chowdhury@ \\ durham.ac.uk \\ ${ }^{3}$ ESCE International Business School, Leadership, Mangement \& Skills Development Department, 10 Rue Sextius Michel, 75016 Paris, \\ France, andres.davila@esce.fr \\ ${ }^{4}$ Free University of Bozen-Bolzano, Faculty of Economics \& Management, Piazza Università 1, 39100 Bolzano, Italy, sascha.kraus@zfke.de \\ ${ }^{5}$ National Taichung University of Science and Technology, Department of Business Management, No.129, Sec. 3, Sanmin Rd., North Dist., \\ Taichung City 40401, Taiwan, Chengcf@nutc.edu.tw \\ www.jsbs.org
}

Keywords:

Entrepreneurial orientation, Sustainable leadership, Psychological characteristics, Integrity, Empowerment

\section{A B S T R A C T}

In this article, we examine how individual-level psychological characteristics such as empowerment, integrity, humility, and need for cognition influence sustainable leadership behavior in firms with levels of high and low entrepreneurial orientation (EO). For this, we utilized fuzzy set qualitative comparative analysis (fsQCA) using data from 2,117 employees working in firms located and operating in different countries and diverse industries. Our results show that specific psychological characteristics possessed by the members of the organizations can be beneficial for engaging in entrepreneurial activity in both high and low EO firms. Our results e.g. show that need for cognition has a differential impact on sustainable leadership behavior in high and low EO firms. However, integrity is essential for a high level of sustainable leadership behavior in both high as well as low EO firms.

\section{Introduction}

Entrepreneurial Orientation (EO) is essential for entrepreneurial activity in organizations as it contributes positively to organizational performance (Semrau et al., 2016). EO is associated with innovativeness, risk-taking, and proactiveness (Covin \& Slevin, 1989), and existing research suggests that leadership behavior influences the EO in organizations (Carraher, 2014; Engelen et al., 2015) by developing the organizational culture (Kunze et al., 2016) and allocating resources (Hambrick \& Mason, 1984). While previous research has examined how leadership behavior influences entrepreneurial activity (e.g., Covin et al., 2020; Covin \& Slevin, 1989; Engelen et al., 2015; Muchiri \& McMurray, 2015; Wales et al., 2020), a critical gap remains in how employees' individual psychological characteristics influence sustainable leadership behavior in entrepreneurially oriented organizations (Adomako et al., 2021; Kraus, Burtscher et al., 2018), as suggested by Wales et al. (2020), “...only a small number of studies examining the antecedents of EO” (p. 12). Additionally, research

Journal of Small Business Strategy

2021, Vol. 31, No. 03, 59-71

ISSN: 1081-8510 (Print) 2380-1751 (Online)

CCopyright 2021 Small Business Institute ${ }^{\circledR}$ related to responsible and sustainable businesses are still emerging (e.g., Chavez et al., 2020; Marcus \& Roy, 2019). To address this gap, we address the following questions: How do employees' psychological characteristics such as empowerment, integrity, humility, and cognition influence sustainable leadership behavior in organizations? How do they differ in different contexts, i.e., high versus low EO firms? By addressing these questions, we aim at gaining insight into how organizations' human resources can promote activities conducive to EO.

We view sustainable leadership as behavior that “... creates and preserves continuous learning, secures success over time, sustains the leadership of others, addresses issues of social justice, develops rather than depletes human and material resources, develops environmental diversity and capacity, and is actively engaged in the environment" (Di Fabio \& Peiró, 2018, p. 1). Leaders and employees can have a bidirectional relationship. A leader may influence individual employees' behavior in the organization through organizational culture (Rigtering et al., 2017) while employees' actions can reflect leader behavior. These interactions influence individuals' characteristics and changes within themselves (Khedhaouria et al., 2015; Maran et al., 2019; Semmer \& Schallberger, 1996).

By examining the relationship between employees' in-

APA Citation Information: Durst, S., Chowdhury, F., Davila, A., Kraus, S., \& Cheng, C. F. (2021). Employees' psychological characteristics and sustainable leadership in firms with high and low entrepreneurial orientation. Journal of Small Business Strategy, 31(3), 59-71. 
dividual psychological characteristics, i.e., empowerment, integrity, humility, cognition, and sustainable leadership behavior in EO firms, we contribute to extant research focusing on the intersection of leadership and entrepreneurship in high and low EO firms (Engelen et al., 2015; Wales et al., 2020). To test the assumptions of this paper, we surveyed 2,117 employees across firms in different industries, suggesting that an organization's members' psychological characteristics can be essential resources for EO firms. Our results furthermore demonstrate the vital interrelation between individuals' psychological traits and entrepreneurial activity. We found that integrity and cognition are essential in high and low EO firms alike, but on different levels. These traits not only influence the selection strategies of HR to develop human capital for realizing the desired outcome, but also contribute to sustainable leadership behavior aimed at supporting entrepreneurial activity.

Second, we contribute to the organizational culture literature by demonstrating the vital role of leadership behavior in motivating employees in low and high EO firms. Using a configurational approach (e.g., Beynon et al., 2016; Kraus, Ribeiro-Soriano et al., 2018; Rigtering et al., 2017) allows us to specify interrelations between a set of interrelated characteristics and better understand the role of psychological traits that influence sustainable leadership behavior.

\section{Theoretical Framework}

\section{Social Exchanges and Sustainable Leadership Behavior}

Social exchange theory suggests that social exchanges involve interactions among individuals that lead to obligations (Emerson, 1976). These interactions tend to be interdependent and often contingent on another person acting (Blau, 1964). The relationship between an organization (employees) and its leaders involves reciprocity and commitment. For leaders to sustain their leadership behavior that helps generate entrepreneurial activities (Kraus, Berchtold et al., 2018; Maran et al., 2019), employees need to be committed to performing their jobs and trust that their efforts will be rewarded (Reichers, 1985). If a supervisor treats his/her subordinates positively, such as providing organizational support or empowering them, then the reciprocating response can lead to commitment (Riggle et al., 2009) and increased employee satisfaction (Suriyankietkaew \& Avery, 2014).

Servant leadership theory suggests that individuals with servant leadership style place others' interests ahead of their own (van Dierendonck, 2011). They create a culture within an organization where employees/followers can grow (Luthans \& Avolio, 2003). This person-oriented attitude leads to positive exchange relationships among members at different management levels, and this positive social exchange motivates employees to behave or engage in activities such as entrepreneurial activities (Bammens, 2016).

\section{Sustainable Leadership Behavior and EO Firms}

Leaders play an essential role in setting an organization's strategic and day-to-day decisions, creating organizational culture, establishing goals (Fernandez, 2008), allocating resources to achieve these goals (Hambrick \& Mason, 1984), setting perceptions regarding organizational climate (Kunze et al., 2016), and empowering the members of the organization to realize the vision and goals (Westley \& Mintzberg, 1989). Compared to traditional leadership behavior, sustainable leadership behavior is a relatively new concept (Avery 2005; Gerard et al., 2017; McCann \& Sweet 2014). Sustainable leaders are concerned with “... creating current and future profits for an organization while improving the lives of all concerned" (McCann \& Holt, 2012, p. 209). Suriyankietkaew and Avery (2014) suggested that sustainable leaders lead by combining stakeholders' values such as personal integrity, ethical behavior, trust, and management practices such as knowledge management and organizational culture to build capacity and skills.

EO firms often reflect strategic leadership behavior and entrepreneurial organization culture (Miller, 1983; Wales et al., 2020). Despite the importance of EO on firm performance, organizations exhibit different EO levels (Adler et al., 1999; Lomberg et al., 2017). Sustained entrepreneurial leadership behavior is a necessary condition for organizations with an entrepreneurial posture, "which are those in which particular behavioral patterns are recurring" (Covin \& Slevin, 1991, p. 8).

\section{Individual-Level Perspective on Sustainable Leadership Behavior}

Employees and leaders have an interlocking two-way relationship since an organization is any social structure or system consisting of two or more interdependent persons that work together in a coordinated manner to attain common goals (Baron, 1987, p. 10). In an EO organization, employees' entrepreneurial behavior is crucial (Ayuso \& Navarrete-Báez, 2018) since they help leaders sustain leadership behavior that is important for entrepreneurial activity. Therefore, empowerment, humility, integrity, and employees' cognitive components can help leaders develop an entrepreneurial culture. 


\section{Empowerment and Sustainable Leadership Behavior}

Empowerment of employees entails transferring decision-making power to them (Kanter, 1977; Lawler et al., 2001) to give them autonomy to execute their work (Seibert et al., 2004). In this paper, empowerment entails the autonomy, power, and accountability employees perceive about their work environment. By transferring decision-making power and autonomy to employees, leaders signal a trusting relationship. Trust between leaders and employees and trust among employees is essential (Dirks \& Ferrin, 2001; Schoorman et al., 2007). In a high EO organization, trust among the members can lead to social capital that maintains sustainable leadership behavior that helps with risk-taking and innovative behavior. On the other hand, a lack of trust can lead to a self-protection mentality, which can negatively affect EO (Colquitt et al., 2011).

Empowerment also means sharing important information and knowledge with employees by giving them access to sensitive information (Bowen \& Lawler, 1995). For a leader to sustain his/her leadership behavior, information and knowledge enable employees to exercise their decision-making power (Robbins et al., 2002). An organization's empowerment culture allows members to share information and knowledge to establish shared mental models among employees (Combs et al., 2006). This shared mental model promotes similar attitudes and beliefs regarding the importance of entrepreneurial behavior and the steps necessary to accomplish tasks for entrepreneurship (Cannon-Bowers \& Salas, 2001). Empowerment enhances employees' human capital by allowing opportunities to take advantage of their knowledge resources and gain knowledge from leaders and followers (Jiang et al., 2012).

Empowerment also allows employees to engage in autonomous action (Robbins et al., 2002). Entrepreneurship-related activities in organizations require individuals to engage in idea generation, and other activities require risk-taking without fear of reprimand (Somech \& Drach-Zahavy, 2013). Empowerment enhances employees' motivation, organizational commitment, and social exchange relationships (Maynard et al., 2012).

Proposition 1. Empowerment is more strongly related to sustained leadership behavior in high EO firms than in low EO firms.

\section{Linking Integrity and Sustainable Leadership Behavior}

The Latin word integritas means "wholeness," "completeness," "honesty," but also "decency" and "modesty." According to Furrow (2005), integrity can be defined as see- ing it as "the extent to which our various commitments form a harmonious, intact whole" (p. 136). Two essential criteria need to be fulfilled: consistency and coherence (McFall, 1987). An individual might be characterized as a person or a whole if she has well-developed ideas and is consistent in pursuing them. It means that individuals make decisions based on the same principles and similarly resolve them in similar situations. Integrity is established early in life and influenced by the family and the immediate environment (Tasoulis et al., 2019).

Research has shown that integrity is crucial not only for leadership but also for a firm's general approach to ethics and governance (Wei et al., 2020). Integrity helps with having healthy, sustainable organizations that operate in favor of all stakeholders. Leadership sets the entire company's tone and expectations (Tasoulis et al., 2019). Furthermore, McCann and Sweet (2014) claim that "if leaders lack integrity and sustainable leadership behaviors, they may be unable to achieve the strategic goals of the organization and may place their organizations in challenging situations that result in compliance issues, poor decision making, morale problems, and communication issues" (p. 381).

Existing research shows that integrity has a bidirectional relationship between employees and leaders' behavior (Simons et al., 2007; Vogelgesang et al., 2013). Often, in an organization, leadership behavior related to integrity can become the organization (Leroy et al., 2012a ; Simons, 2002). If the leadership behavior does not reflect integrity, it reflects poorly on the organization, and this lack of integrity spills over to the employees (Simons et al., 2007; Vogelgesang et al., 2013). Empirical studies suggest a positive relationship between employees' integrity and sustainable leadership behavior through organizational commitment (Leroy et al., 2012a, b). If a leader is perceived as having high levels of integrity by the employees, then trust between leaders can be built, which in turn can increase work engagement, improved commitment, and job satisfaction (Avolio \& Gardner, 2005; Tasoulis et al., 2019), displaying the power of this trait. Individuals with high levels of integrity focus on developing and maintaining caring relationships (Dunn, 2009).

Employees' lack of integrity has negative consequences for an organization's entrepreneurship-related activity through employees' lack of commitment to an organization. Entrepreneurial activity tends to flourish in an organization where leaders support these activities (Vecchio, 2003) at a good time and at a time of crisis. Leaders show support for entrepreneurial activities through their behavior. If employees do not have integrity and do not trust that their leaders have integrity, they may scale back their entrepreneurial activity (Greenberg, 1990; Meyer et al., 2017). For instance, 
if employees believe that they will not be treated fairly by their leaders for undertaking the entrepreneurial activity, they may not be committed to their activity. Greenberg's (1990) study shows that employees' commitment to the organization is affected by their belief that their efforts will be rewarded; they believe that leaders have integrity. Therefore, having a workforce with integrity can be crucial for entrepreneurial-oriented organizations.

Proposition 2. Integrity is more strongly related to sustained leadership behavior in high EO firms than in low EO firms.

\section{Relationship between Humility and Sustainable Leader- ship Behavior}

Humility is viewed as a stable personality trait (Sun, 2013). A person possessing this attribute "is able to put aside, or even abandon altogether, his or her position, accomplishment, and talents, in order to utilize the talents of others" (Sun, 2013, p. 548). Marcus and Roy (2019) found that the existence of the Honesty-Humility trait appears to be a safeguard against unethical and harmful behaviors in organizations.

Humility can be an essential character for both employees and leaders to sustain the leadership behavior conducive to an organization's entrepreneurial activity. Entrepreneurial activity often entails team members working together to bring a project to fusion. Employees' and leaders' humility can influence their emotions, influencing their cognition, decision-making, and behavior (Isen, 1993; Baron, 2008). Employees with humility can understand their strengths and weaknesses and appreciate team members' strengths. Sustainable leadership behavior in Entrepreneurial Firms entails learning from others. Both the leaders' and members' humility enable them to learn from each other (Wang et al., 2017). In high EO firms, a learning environment can influence the firms' entrepreneurship-related activity. Humble leaders can set an example of having an open-mind by showing they understand their limitations and are willing to learn from others.

Humble leaders can also reduce the faultlines - fractures within teams in an organization; faultlines influence team performance through conflicts in teams, reduced collaboration, and less willingness to share task-related information (Antino et al., 2019). Entrepreneurial activity within organizations requires team involvement and productive team performance. Team members often have a diverse background, an experience that influences their cognition and contribution to the team (van Knippenberg et al., 2004). While diverse experience can positively impact team perfor- mance, managing diversity can be an essential component for sustainable entrepreneurial activity in an organization (Joshi \& Roh, 2009); it also is a hindrance to entrepreneurial activity (Thatcher \& Patel, 2012). Humble leaders can influence employees' attitudes and behavior through social cues such as listening to different views and understanding different viewpoints. (Griffin, 1983; Owens \& Hekman, 2012).

Humility in organizations can also promote creativity in an organization. Creativity is an essential component of high entrepreneurship-oriented organizations. Existing research suggests that leaders' humility influences employees' creativity (Wang et al., 2017) by appealing to their achievement needs. McClelland (1961) suggests that entrepreneurial individuals have a strong need for achievement. Humble leaders can appeal to their needs by communicating that mistakes are tolerated, and learning from failure is welcome, both of which are important for entrepreneurial-oriented organizations (Owens et al., 2013; Shepherd, 2003). This social cue can influence attitudes toward entrepreneurial activity (Hon et al., 2013; Zhang \& Bartol, 2010).

Proposition 3. Humility is more strongly related to sustained leadership behavior in high EO firms than in low EO firms.

\section{Linkage between Need for Cognition and Sustainable Leadership Behavior}

In this paper, we align our view of the need for cognition with Cacioppo et al. (1984). The study refers to the need for cognition (NC henceforth) as an "individual's tendency to engage in and enjoy effortful cognitive endeavors" (p. 306). Thus, people high in NC thinking get enjoyment and satisfaction from complex problems, while people low in NC thinking view complex problems as a burdensome obligation and only engage in them when some incentive and (or) reason is present (Petty et al., 2009). In a high EO organization, the psychological trait, need for cognition, is needed since situations might arise when employees and leaders need to "rethink current strategic actions, organization structure, communication systems, corporate culture, asset deployment, investment strategies, in short, every aspect of an organization's operation and long-term health" (Hitt et al., 1998, p. 26). Therefore, both sustainable leadership and employees require NC.

Cognition requires knowledge and information and an individual's capacity to work with this knowledge/information. In this context, general intelligence is one critical aspect, yet domain-specific cognitive skills (i.e., skills that emerge through experience and active practice) may be 
more critical when considering a person's emergence and performance, such as leaders (Mumford et al., 2015). Previous research has found that people high in NC are not only engaged in more thinking about all kinds of information, they are also more aware of their thinking, which Schraw and Dennison (1994) call metacognition. Metacognition allows an individual to understand their ability, control information processing, and reflect on their learning. Tam and Ho (2005), who studied the effects of web specialization in the context of persuasion, found that people low in NC have little motivation to exert cognitive effort to evaluate the merits of alternative information and processing. They tend to rely on recommendations provided by personalized agents. In high EO firms, low NC tends to be less productive than high NC individuals, as Wu et al. (2014) study suggested. The study found a positive association between $\mathrm{NC}$ and innovative behavior.

In EO firms, leaders need to motivate employees to engage in entrepreneurial activity, and while engaged in these activities, unexpected situations may arise. To sustain entrepreneurial activity in organizations, leaders also need to maintain their behavior to sustain entrepreneurial activity. Existing research shows that leaders' cognition is essential for resource accessibility, providing support when there is a lack of social/structural support (Mumford et al., 2007). Leaders' cognition is also crucial for framing a problem, gaining support for their projects, identifying alternatives for solutions (Gröschl et al., 2019; Partlow et al., 2015). Studies also suggest that sustainable leadership behavior is crucial for organizations to outperform during crises (McCann \& Sweet, 2014; Varma, 2020).

Proposition 4. Need for cognition is more strongly related to sustained leadership behavior in high EO firms than in low EO firms.

\section{Method}

\section{Data Description and Sample}

The data used in this article was collected by the private research company Praditus, www.praditus.com, which is recognized by the French Ministry of Research and Education. The company provides a web and mobile application on which companies offer their employees from across the globe behavioral measures scientifically validated and aligned with their company's values and leadership models. Employees with different roles within the organization can freely use the platform as part of their development journey during their tenure with the company. In exchange, employees receive feedback on their profile and opportunities for development.

In the present study, the sample consists of 2,117 employees, of which $39.1 \%$ are female, and $48.5 \%$ are male; $12.4 \%$ did not provide any information. This sample was selected randomly from a data set containing more than 70 million $(1$ item $=$ one answer $)$ answers for various scales. We selected all employees who responded to all the dimensions relevant for the present study.

The firms involved are representing different countries (e.g., France, Germany, Italy, Spain, the UK etc.) and operating in diverse industries (i.e., aeronautics; banking; car rentals; energy and construction; executive education; transportation; pharmaceutics; retail; services; and telecommunications). Members of the firms were invited to participate anonymously via email and linked to an established online survey system. All the constructs and scales were implemented in this platform in 2019 as part of leadership development programs. Unlike most other academic research, the way Praditus is collecting its data is neither cross-sectional nor longitudinal, but rather potentially never-ending. (Although for this work here, of course, data has been extracted at one single point of time.)

\section{Outcome Variable}

To measure sustainable leadership behavior, we adapted the measures from Di Fabio and Peiró (2018), consisting of the following items: 1) I create sustainable learning conditions that I take care to preserve, 2) I develop, rather than exhaust, the human resources that work with me, 3) I support my collaborators in their personal/career growth, 4) I leave out the superfluous by focusing resources on the crucial aspects of work. For both the outcome variable as well as for the explanatory factors, respondents were asked to select their choice on the 5-point Likert scale from $1=$ totally disagree to $5=$ totally agree.

\section{Explanatory Factors (Conditions)}

We adapted our measures for empowerment from Spreitzer (1995). Respondents were asked the following questions: 1) The work I do is very important to me; 2) My job activities are personally meaningful to me; 3) The work I do is meaningful to me; 4) I am confident about my ability to do my job; 5) I am self-assured about my capabilities to perform my work activities; 6) I have mastered the skill necessary to perform my job; 7) I have significant autonomy in determining how I do my job; 8) I can decide on my own to go about doing my work; 9) I have considerable opportunity for independence and freedom in how I do my job; 10) My impact on what happens in my department is 
large; 11) I have a great deal of control over what happens in my department; 12) I have significant influence over what happens in my department. Integrity was measured by the following questions developed by Black and Reynolds (2016): 1) I try hard to act honestly in most things I do; 2) Not hurting other people is one of the rules I live by; 3 ) It is important for me to treat other people fairly; 4) I want other people to know they can rely on me; 5) I always act in ways that do the most good and least harm to other people; 6) If doing something will hurt another person, I try to avoid it even if no one would know; 7) One of the most important things in life to do what you know is right; 9) I always keep my promises; 10) I am true to my own values; 11) Once I've made up my mind about what is the right thing to do I make sure I do it.

Humility was measured based on the following questions adapted from de Vries (2013): 1) I find it difficult to lie; 2) I would like to know how to make lots of money in a dishonest manner; 3) I want to be famous; 4) I am entitled to special treatment. For the last three items, the scale was reversed.

For need for cognition, we used measures developed by Cacioppo and Petty (1982) and Tam and Ho (2005): 1) I prefer to do something that challenges my thinking abilities rather than something that requires little thought; 2) I prefer complex problems to simple problems; 3) I don't like to have to do a lot of thinking; 4) I try to avoid situations that require thinking in-depth about something; 5) Thinking hard and for a long time about something gives me little satisfaction.

Entrepreneurial orientation was assessed with its separate dimensions of innovativeness (three items), proactiveness (three items), and risk-taking (six items), using items based on Covin et al. (2020).

Item-to-total correlations and Cronbach's $\alpha$ are measures of internal consistency that range from 0 to 1 . Values of item-to-total correlations indicate the correlations of the item to the summated scale score, and Cronbach's $\alpha$ indicates how closely related a set of items are as a group. Most values of item-to-total correlations exceed or were close to 0.5 , while the values of Cronbach's $\alpha$ exceed or were close to 0.6. In addition to the values of Cronbach's $\alpha$, Table 1 displays also the Kaiser-Meyer-Olkin (KMO) values for the items. Table 2 shows the description of individuals (e.g., gender, education, position).

\section{Analysis}

Data were analyzed using the fuzzy-set qualitative comparative analysis (fsQCA) technique. Compared to the standard regression techniques based on correlations and
Table 1

Values of KMO and Cronbach's Alpha

\begin{tabular}{lccc}
\hline & $\begin{array}{c}\text { N of } \\
\text { Items }\end{array}$ & KMO & $\begin{array}{c}\text { Cronbach's } \\
\text { Alpha }\end{array}$ \\
\hline $\begin{array}{l}\text { Sustainable } \\
\text { Leadership Behavior }\end{array}$ & 4 & 0.663 & 0.604 \\
Empowerment & 12 & 0.815 & 0.852 \\
Integrity & 8 & 0.758 & 0.734 \\
Humility & 4 & 0.605 & 0.431 \\
Cognition & 5 & 0.774 & 0.771 \\
\hline
\end{tabular}

Table 2

Description of individual respondents

\begin{tabular}{|c|c|c|c|}
\hline Variable & & Frequency & Percent \\
\hline \multirow{4}{*}{$\begin{array}{l}\text { Business } \\
\text { Responsibility }\end{array}$} & Director & 575 & 27.20 \\
\hline & Employee & 866 & 40.90 \\
\hline & Manager & 592 & 28.00 \\
\hline & N. A. & 84 & 4.00 \\
\hline \multirow{3}{*}{$\begin{array}{l}\text { Gender of } \\
\text { Respondents }\end{array}$} & Female & 827 & 39.10 \\
\hline & Male & 1026 & 48.50 \\
\hline & N. A. & 264 & 12.50 \\
\hline \multirow{6}{*}{$\begin{array}{l}\text { Years of } \\
\text { Experience }\end{array}$} & less than 1 year & 33 & 1.60 \\
\hline & $1-5$ years & 166 & 7.80 \\
\hline & $5-10$ years & 227 & 10.70 \\
\hline & $\begin{array}{l}\text { more than } 10 \\
\text { years }\end{array}$ & 1591 & 75.20 \\
\hline & N.A. & 100 & 4.70 \\
\hline & Bachelors & 299 & 14.10 \\
\hline \multirow[t]{8}{*}{ Degree } & Engineer & 397 & 18.80 \\
\hline & $\begin{array}{l}\text { High School } \\
\text { diploma }\end{array}$ & 75 & 3.50 \\
\hline & Masters & 943 & 44.50 \\
\hline & $\mathrm{PhD}$ & 67 & 3.20 \\
\hline & Technical degree & 207 & 9.80 \\
\hline & Other diplomas & 6 & 0.30 \\
\hline & No degree & 22 & 1.00 \\
\hline & N. A. & 101 & 4.80 \\
\hline
\end{tabular}

assumed symmetry, fsQCA does not have the symmetry restrictions (Beynon et al., 2016; Kraus, Ribeiro-Soriano et al., 2018). Moreover, in comparison with variable-based approaches, fsQCA uses a set-theoretic approach or asymmetric thinking in data analysis and focuses on configurations for testing social science theories or assumptions 
rather than having a net effect estimation approach. In other words, fsQCA can further produce causal conditions that are sufficient for the outcome based on Boolean algebra. fsQCA is consistent with set-theory and formal logic. A fsQCA allows translation of the causal principle of QCA a binary representation of the presence of some conditions for a given (also binary) outcome - to continuous variables by introducing fuzzy sets that represent the magnitude of membership (e.g., 0.05 for non-membership, 0.95 for full membership, 0.5 for crossover membership). According to the user's guide to fsQCA from Ragin (2017), this study set original values of 1.0, 5.0, and 3.0 from a 5-point Likerttype scale into a fuzzy set to correspond to these memberships. In the second step, this study contributed to combine relevant antecedents (i.e., empowerment, integrity, humility, and need for cognition) into various configurations to identify sufficient conditions for achieving high sustainable leadership behavior in high and low entrepreneurial oriented firms. Therefore, there were 16 (i.e., $2^{4}$ ) logically possible combinations of values on the causal conditions in the truth table. This study recognized configurations by specifying the consistent cutoff value as .75 and the number-of-cases threshold as one and then used standard analysis to generate the solution. Ragin (2017) indicated that standard analysis could provide complex, parsimonious, and intermediate solutions, and partial logical remainders are incorporated into the intermediate solution. Accordingly, this study employed intermediate solutions of standard analysis to explore sufficient conditions for achieving high sustainable leadership behavior.

Following similar studies using fsQCA in an entrepreneurship context (e.g., Palmer et al., 2019), the sample was split into two groups; a group high on entrepreneurial orientation and a group low on entrepreneurial orientation. These two groups were developed based on the mean (i.e., 2.8858) of the summated scale (i.e., EO, entrepreneurial orientation) of risk-taking, proactiveness, and innovativeness.

\section{Results}

Table 3 highlights all configurations. The solid black circles represent the presence of a variable (condition), white circles represent the absence (negation) of a variable, and black cells represent the irrelevance/do not care condition for sustainable leadership behavior (Ragin, 2008). These six combinations are relevant for organizations high and low on entrepreneurial orientation. As there is more than one configuration, one can assume several alternative paths to sustainable leadership behavior.

\section{Table 3}

Results of $f_{S} Q C A$ - Explaining sustainable leadership behavior

\section{Combination to Sustainable Leadership Behavior}

\begin{tabular}{|c|c|c|c|c|c|c|}
\hline \multirow[b]{2}{*}{ Condition } & \multicolumn{3}{|c|}{ High EO Firms $(n=1129)$} & \multicolumn{3}{|c|}{ Low EO Firms $(n=988)$} \\
\hline & A1 & A2 & A3 & B1 & B2 & B3 \\
\hline Empowerment & & & $\bullet$ & & & $\bullet$ \\
\hline Integrity & $\bullet$ & $\bullet$ & & $\bullet$ & $\bullet$ & \\
\hline Humility & & $\bullet$ & & & $\bullet$ & \\
\hline Cognition & $\bullet$ & & $\bullet$ & o & & $\bullet$ \\
\hline Consistency & 0.99 & 0.97 & 0.99 & 0.97 & 0.96 & 0.97 \\
\hline Raw Coverage & 0.95 & 0.93 & 0.95 & 0.96 & 0.96 & 0.97 \\
\hline Unique Coverage & 0 & 0.02 & 0 & 0 & 0.02 & 0.01 \\
\hline Solution Consistency & 0.97 & & & 0.99 & & \\
\hline Solution Coverage & 0.98 & & & 0.95 & & \\
\hline
\end{tabular}

Table 3 also presents all-important consistency and coverage statistics for all configurations. All consistency and coverage values shown in the table comply with the required levels. The solution consistency values are also at least 0.74 , indicating that the configurations are sufficient conditions leading to sustainable leadership behav- ior (Ragin, 2008). For example, this means that in terms of consistency (A2), 97\% of the firms are characterized by sustainable leadership behavior when they possess the presented combination of antecedent and characteristics. Coverages represent information about the proportion of cases that explain the outcome; our smallest coverage is 0.93 
(A2), suggesting that a significant proportion of cases are being explained. All three paths for the high Entrepreneurial Firms explain that $98 \%$ of sustainable leadership behavior, while three paths for the low Entrepreneurial Firms explain $95 \%$.

\section{Causal Configurations for Organizations High on En- trepreneurial Orientation}

Three paths can explain sustainable business behavior by organizations high on entrepreneurial orientation. All paths fulfill the minimum requirements for consistency $(>$ $0.75)$. Additionally, all conditions assumed to influence sustainable leadership behavior are relevant in at least one of the three paths. Path A1 indicates that the presence of integrity in combination with cognition contributes to sustainable leadership behavior. In this path, empowerment and humility are absent. Path A2 shows that organizations high on entrepreneurial orientation can have sustainable leadership behavior when integrity and humility are present. Path A3, on the other hand, suggests that sustainable leadership behavior can be reached through empowerment and cognition.

\section{Causal Configurations for Organizations Low on Entre- preneurial Orientation}

Three paths can also explain sustainable leadership behavior by organizations low on entrepreneurial orientation. Path B1 indicates that the presence of integrity contributes to sustainable leadership behavior when cognition is absent. Paths B2 and B3 are the same as Paths A2 and A3.

\section{Discussion and Conclusion}

Existing literature has examined the influence of top management style and other organizational configurations and their influence on EO. There are limited studies that have examined how an important resource, employees characteristics, fits in this model. By employing a configurational fsQCA, in this paper, we examined the relationship between employees' psychological characteristics and sustainable leadership behavior in EO firms. Interestingly, results show that combinations of psychological traits (empowerment, integrity, humility, and need for cognition) and their influence on sustainable leadership behavior are consistent across the study's organizations. Rather, the EO of an organization dictates the benefit of the psychological characteristics.

In Proposition 1, we assumed that empowerment would positively influence sustainable leadership behavior in high EO firms. Our results indicate that empowerment is not a significant component for sustainable leadership in either high or low EO firms. In Proposition 2, we assumed that integrity would have a positive influence on sustainable leadership behavior. Our findings indicate integrity to be important in two out of three combinations for high and low EO firms. In Propositions 3 and 4, we assumed humility and cognition would be positively associated with sustainable leadership behavior. The findings suggest that there is more robust support for Proposition 4 than for Proposition 3. In other words, the configurations for high and low EO are similar but not necessarily identical. One difference found is for path $\mathrm{A} 1$ (organizations high on EO) and B1 (organizations low on EO). In a high EO organization, both integrity and cognition can promote sustainable leadership behavior, while in a low EO organization, the presence of integrity and absence of cognition can contribute to sustainable leadership behavior. This difference is likely to be explained by the fact that in organizations high on EO, more employees want to actively drive innovation or entrepreneurial activities than the employees in organizations low on EO.

Entrepreneurship literature has long viewed resources such as human capital, knowledge, and entrepreneurial mindset as necessary resources for organizations' entrepreneurial activity (Davidsson \& Honig, 2003; McGrath \& MacMillan, 2000). Ireland et al. (2003) suggested that cognition is vital for decision-making in a dynamic environment where goals are changing, and this change brings in new opportunities. Our study results indicate that the need for cognition that allows members of an organization to adapt to the changing environment is also associated with integrity. A combination of both the need for cognition and integrity are essential resources for an organization's members. People generally firmly hold on to their moral identity since they want to maintain self-consistency (Blasi, 2004) that often motivates their actions. Therefore, the integrity of a group/member of the organization can be an essential resource in an entrepreneurial firm since they often have to attain resources from external sources.

In EO firms, the leaders can help develop or strengthen the integrity of the organizations. This finding is fascinating and relevant for the EO literature as it adds to the understanding of the link between EO and sustainable leadership behavior that influence firm performance, thus contributing to recent debates (Adomako et al., 2021; Wales et al., 2020). As regards the latter, it underlines, in particular, the need for leaders to have an in-depth understanding of the people and their characteristics. Additionally, suggesting the organizational context is vital to consider for leadership.

Our findings have practical implications too. First, for practitioners, such as managers, it is crucial to understand 
that there is more than just one way to see sustainable leadership behavior in EO firms. This study already provides six paths that lead to sustainable leadership behavior. The study further implies that firms should also understand the importance of employees' psychological characteristics to lead sustainably. Moreover, being low (high) on EO does not necessarily have to result in underdeveloped sustainable leadership behavior. The findings should be interesting for organizations' HR departments, too, as they provide useful information for training and further education towards sustainable business practices in Entrepreneurial Firms.

\section{Limitations}

As with every research, our study has some limitations. First, even though fsQCa helps us identify causal configurations, this approach only allows one outcome variable (Kent $\&$ Argouslidis, 2005). Furthermore, there could be other psychological traits for sustainable leadership behavior to consider. Future research could address these limitations and further develop the study results by exploring different paths for different types of organizations to improve sustainable leadership behavior in more depth. Scholars should also examine approaches to sustainable leadership behavior among organizations low on EO and organizations high on EO operating in distinct business contexts. Institutional and socio-cultural structures may influence the desirability of sustainable leadership behavior.

\section{References}

Adler, N. J. (1999). Global entrepreneurs: Women, myths and history. Global Focus, 11(4), 125-134.

Adomako, S., Amankwah-Amoah, J., Danso, A., \& Dankwah, G. O. (2021). Chief executive officers'sustainability orientation and firm environmental performance: Networking and resource contingencies. Business Strategy and the Environment, 30(4), 2184-2193. https://doi-org.libraryproxy.his.se/10.1002/bse.2742.

Antino, M., Rico, R.., \& Thatcher, S. M. (2019). Structuring reality through the faultlines lens: The effects of structure, fairness, and status conflict on the activated faultlines-performance relationship. Academy of Management Journal, 62(5), 1444-1470.

Avery, G. (2005). Leadership for sustainable futures: Achieving success in a competitive world. Edward Elgar.

Avolio, B. J., \& Gardner, W. L. (2005). Authentic leadership development: Getting to the root of positive forms of leadership. The Leadership Quarterly, 16(3), 315-338.

Ayuso, S., \& Navarrete-Báez, F. E. (2018). How does en- trepreneurial and international orientation influence SMEs' commitment to sustainable development? Empirical evidence from Spain and Mexico. Corporate Social Responsibility and Environmemtal Management, 25(1), 80-94.

Bammens, Y. P. (2016). Employees' innovative behavior in social context: A closer examination of the role of organizational care. Journal of Product Innovation Management, 33(3), 244-259.

Baron, R. A. (2008). The role of affect in the entrepreneurial process. Academy of Management Review, 33(2), $328-340$.

Baron, R. A. (1987). Behavior in organizations: Understanding and managing the human side of work. (2 ed). Allyn and Bacon.

Beynon, M. J., Jones, P., \& Pickernell, D. (2016). Country-based comparison analysis using fsQCA investigating entrepreneurial attitudes and activity. Journal of Business Research, 69(4), 1271-1276.

Black, J. E., \& Reynolds, W. M. (2016). Development, reliability, and validity of the Moral Identity Questionnaire. Personality and Individual Differences, 97, $120-129$.

Blasi, A. (2004). Moral functioning: Moral understanding and personality. In D.K. Lapsley \& D. Narvaez (Eds.), Moral Development, Self, and Identity (pp. 335-347). Lawrence Erlbaum Associates Publishers.

Blau, P. M. (1964). Justice in social exchange. Sociological Inquiry, 34(2), 193-206.

Bowen, D. E., \& Lawler III, E. E. (1995). Empowering service employees. MIT Sloan Management Review, 36(4), 73.

Cacioppo J. T., \& Petty, R. E. (1982). The need for cognition. Journal of Personality and Social Psychology, 42(1), 116-131.

Cacioppo, J. T., Petty, R. P., \& Kao, C. F. (1984). The efficient assessment of need for cognition. Journal of Personality Assessment, 48(3), 306-307.

Cannon-Bowers, J. A., \& Salas, E. (2001). Reflections on shared cognition. Journal of Organizational Behavior: The International Journal of Industrial, Occupational and Organizational Psychology and Behavior, 22(2), 195-202.

Carraher, S. (2014). Leadership, entrepreneurship, and suggestions for future research. Journal of Management History, 20(1). https://doi.org/10.1108/JMH-08-20130038

Chavez, R., Yu, W., Sadiq Jajja, M. S., Lecuna, A., \& Fynes, B. (2020). Can entrepreneurial orientation improve sustainable development through leveraging internal lean practices? Business Strategy and the Environ- 
ment, 29(6), 2211-2225.

Colquitt, J., Lepine, J. A., Wesson, M. J., \& Gellatly, I. R. (2011). Organizational behavior: Improving performance and commitment in the workplace (Vol. 375). McGraw-Hill Irwin.

Combs, J., Liu, Y., Hall, A., \& Ketchen, D. (2006). How much do high-performance work practices matter? A meta-analysis of their effects on organizational performance. Personnel Psychology, 59(3), 501- 528.

Covin, J. G., Rigtering, J. P. C., Hughes, M., Kraus, S., Cheng, C. F., \& Bouncken, R. B. (2020). Individual and team entrepreneurial orientation: Scale development and configurations for success. Journal of Business Research, 112, 1-12.

Covin, J. G., \& Slevin, D. P. (1991). A conceptual model of entrepreneurship as firm behavior. Entrepreneurship Theory and Practice, 16(1), 7-26.

Covin, J. G., \& Slevin, D. P. (1989). Strategic management of small firms in hostile and benign environments. Strategic Management Journal, 10(1), 75-87.

Davidsson, P., \& Honig, B. (2003). The role of social and human capital among nascent entrepreneurs. Journal of Business Venturing, 18(3), 301-331.

de Vries, R. E. (2013). The 24-item Brief HEXACO Inventory (BHI). Journal of Research in Personality, 47(6), 871-880.

Di Fabio A., \& Peiró, J. (2018). Human capital sustainability leadership to promote sustainable development and healthy organizations: A new scale. Sustainability, 10(7), 2413.

Dirks, K. T., \& Ferrin, D. L. (2001). The role of trust in organizational settings. Organization Science, 12(4), 450-467.

Dunn, C. P. (2009). Integrity matters. International Journal of Leadership Studies, 5(1), 102-126.

Emerson, R. M. (1976). Social exchange theory. Annual Review of Sociology, 2(1), 335-362.

Engelen, A., Gupta, V., Strenger, L., \& Brettel, M. (2015). Entrepreneurial orientation, firm performance, and the moderating role of transformational leadership behaviors. Journal of Management, 41(4), 1069-1097.

Fernandez, S. (2008). Examining the effects of leadership behavior on employee perceptions of performance and job satisfaction. Public Performance and Management Review, 32(2), 175-205.

Furrow, D. (2005). Ethics: Key concepts in philosophy. Continuum International Publishing Group.

Gerard, L., McMillan, J., \& D’Annunzio-Green, N. (2017). Conceptualising sustainable leadership. Industrial and Commercial Training, 49(3), 116-126.

Greenberg, J. (1990). Organizational justice: Yesterday, today, and tomorrow. Journal of Management, 16(2), 399-432.

Griffin, R. W. (1983). Objective and social sources of information in task redesign: A field experiment. Administrative Science Quarterly, 28(2), 184-200.

Gröschl, S., Gabaldón, P., \& Hahn, T. (2019). The co-evolution of leaders' cognitive complexity and corporate sustainability: The case of the CEO of Puma. Journal of Business Ethics, 155(3), 741-762.

Hambrick, D. C., \& Mason, P. A. (1984). Upper echelons: The organization as a reflection of its top managers. Academy of Management Review, 9(2), 193-206.

Hitt, M. A., Keats, B. W., \& DeMarie, S. (1998). Navigating in the new competitive landscape: Building strategic flexibility and competitive advantage in the 21 st century. Academy of Management Executive, 12(4), 22-42.

Hon, A. H., Chan, W. W., \& Lu, L. (2013). Overcoming work-related stress and promoting employee creativity in hotel industry: The role of task feedback from supervisor. International Journal of Hospitality Management, 33, 416-424.

Ireland, R. D., Hitt, M. A., \& Sirmon, D. G. (2003). A model of strategic entrepreneurship: The construct and its dimensions. Journal of Management, 29(6), 963-989.

Isen, A. M. (1993). Positive affect and decision making. In M. Lewis \& J. Haviland-Jones (Eds.), Handbook of emotions (pp. 261-277). Guilford.

Jiang, K., Lepak, D. P., Hu, J., \& Baer, J. C. (2012). How does human resource management influence organizational outcomes? A meta-analytic investigation of mediating mechanisms. Academy of Management Journal, 55(6), 1264-1294.

Joshi, A., \& Roh, H. (2009). The role of context in work team diversity research: A meta-analytic review. Academy of Management Journal, 52(3), 599-627.

Kanter, R. M. (1977). Men and women of the corporation. Basic Books.

Kent, R. A., \& Argouslidis, P. C. (2005). Shaping business decisions using fuzzy-set analysis: Service elimination decisions. Journal of Marketing Management, 21(56), 641-658.

Khedhaouria, A., Gurău, C., \& Torrès, O. (2015). Creativity, self-efficacy, and small-firm performance: The mediating role of entrepreneurial orientation. Small Business Economics, 44(3), 485-504. DOI 10.1007/s11187-0149608-y

Kraus, S., Berchtold, J., Palmer, C., \& Filser, M. (2018). Entrepreneurial orientation: the dark triad of executive personality. Journal of Promotion Management, 24(5), 715-735.

Kraus, S., Burtscher, J., Vallaster, C., \& Angerer, M. (2018). 
Sustainable Entrepreneurship Orientation: A Reflection on Status-Quo Research on Factors Facilitating Responsible Managerial Practices. Sustainability, 10(2), 444. https://doi.org/10.3390/su10020444

Kraus, S., Ribeiro-Soriano, D., \& Schüssler, M. (2018). Fuzzy-set qualitative comparative analysis (fsQCA) in entrepreneurship and innovation research-the rise of a method. International Entrepreneurship and Management Journal, 14(1), 15-33.

Kunze, F., De Jong, S. B., \& Bruch, H. (2016). Consequences of collective-focused leadership and differentiated individual-focused leadership: Development and testing of an organizational-level model. Journal of Management, 42(4), 886-914.

Lawler III, E. E., Mohrman, S., \& Benson, B. (2001). Organizing for high performance: Employee involvement, $T Q M$, reengineering, and knowledge management in the fortune 1000. The CEO report. Jossey-Bass.

Leroy, H., Palanski, M., \& Simons, T. (2012a). How being true to the self helps leaders walk the talk: Authentic leadership and leader behavioral integrity as drivers of follower affective organizational commitment and work role performance. Journal of Business Ethics, 107(3), 255-264.

Leroy, H., Dierynck, B., Anseel, F., Simons, T., Halbesleben, J. R. B., McCaughey, D., Savage, G., \& Sels, L. (2012b). Behavioral integrity for safety, priority of safety, psychological safety, and patient safety: A team-level study. Journal of Applied Psychology, 97(6), 1273-1281.

Lomberg, C., Urbig, D., Stöckmann, C., Marino, L. D., Dickson, P. H. (2017). Entrepreneurial Orientation: The dimensions' shared effects in explaining firm performance. Entrepreneurship Theory and Practice, 41(6), 973-998.

Luthans, F., \& Avolio, B. J. (2003). Authentic leadership development. Positive Organizational Scholarship, 241, 258.

Maran, T., Furtner, M., Kraus, S., Liegl, S., \& Jones, P. (2019). Entrepreneurial leadership: An experimental approach investigating the influence of eye contact on motivation. Journal of Small Business Strategy, 29(3), 16-32.

Marcus, J., \& Roy, J. (2019). In search of sustainable behaviour: The role of core values and personality traits. Journal of Business Ethics, 158(1), 63-79.

Maynard, M. T., Gilson, L. L., \& Mathie, J. E. (2012). Empowerment - fad or fab? A multilevel review of the past two decades of research. Journal of Management, 38(4), 1231-1281.

McCann, J., \& Holt, R. (2012). Defining sustainable lead- ership. International Journal of Sustainable Strategic Management, 2(2), 204-210.

McCann, J., \& Sweet, M. (2014). The perceptions of ethical and sustainable leadership. Journal of Business Ethics, 121(3), 373-383.

McClelland, D. C. (1961). The achievement society. Von Nostrand.

McFall, L. (1987). Integrity. Ethics. 98(1), 5-20.

McGrath, R. G., \& MacMillan, I. C. (2000). The entrepreneurial mindset: Strategies for continuously creating opportunity in an age of uncertainty. (Vol. 284). Harvard Business Press.

Meyer, F., Le Fevre, D. M., \& Robinson, V. M. (2017). How leaders communicate their vulnerability: Implications for trust building. International Journal of Educational Management, 31(2), 221-235.

Miller, D. (1983). The correlates of entrepreneurship in three types of firms. Management Science, 29(7), 770-792.

Muchiri, M., \& McMurray, A. (2015). Entrepreneurial orientation within small firms: A critical review of why leadership and contextual factors matter. Small Enterprise Research, 22(1), 17-31.

Mumford, M. D., Watts, L. L., \& Partlow, P. J. (2015). Leader cognition: Approaches and findings. The Leadership Quarterly, 26(3), 301-306.

Mumford, M. D., Friedrich, T. L., Caughron, J. J., \& Byrne, C. L. (2007). Leader cognition in real-world settings: How do leaders think about crises? The Leadership Quarterly, 18(6), 515-543.

Owens, B. P., Johnson, M. D., \& Mitchell, T. R. (2013). Expressed humility in organizations: Implications for performance, teams, and leadership. Organization Science, 24(5), 1517-1538.

Owens, B. P., \& Hekman, D. R. (2012). Modeling how to grow: An inductive examination of humble leader behaviors, contingencies, and outcomes. Academy of Management Journal, 55(4), 787-818.

Palmer, C., Niemand, T., Stöckmann, C., Kraus, S., \& Kailer, N. (2019). The interplay of entrepreneurial orientation and psychological traits in explaining firm performance. Journal of Business Research, 94, 183-194.

Partlow, P. J., Medeiros, K. E., \& Mumford, M. D. (2015). Leader cognition in vision formation: Simplicity and negativity. The Leadership Quarterly, 26(3), 448-469.

Petty, R., Brinol, P., Loersch, C., \& McCaslin, M. J. (2009). The Need for Cognition. In M. R. Leary \& R. H. Hoyle (Eds.), Handbook of individual differences in social behaviour (pp. 318-329). Guildford Press.

Ragin, C. C. (2008). Redesigning social inquiry: Fuzzy sets and beyond. University of Chicago Press.

Ragin, C. C. (2017). User's guide to fuzzy-set/qualitative 
comparative analysis. UCI School of Social Sciences. www.fsqca.com.

Reichers, A. E. (1985). A review and reconceptualization of organizational commitment. Academy of Management Review, 10(3), 465-476.

Riggle, R. J., Edmondson, D. R., \& Hansen, J. D. (2009). A meta-analysis of the relationship between perceived organizational support and job outcomes: 20 years of research. Journal of Business Research, 62(10), 10271030.

Rigtering, J. P. C., Eggers, F., Kraus, S., \& Chang, M. L. (2017). Entrepreneurial orientation, strategic planning and firm performance: The impact of national cultures. European Journal of International Management, 11(3), 301-324.

Robbins, T. L., Crino, M. D., \& Fredendall, L. D. (2002). An integrative model of the empowerment process. Human Resource Management Review, 12(3), 419-43.

Schoorman, F. D., Mayer, R. C., \& Davis, J. H. (2007). An integrative model of organizational trust: Past, present, and future. Academy of Management Review, 32(2). https://doi.org/10.5465/amr.2007.24348410

Schraw, G., \& Dennison, R. (1994). Assessing metacognitive awareness. Contemporary Educational Psychology, 19(4), 460-475.

Semmer, N., \& Schallberger, U. (1996). Selection, socialisation, and mutual adaptation: Resolving discrepancies between people and work. Applied Psychology: An International Review, 45(3), 263-288.

Semrau, T., Ambos, T., \& Kraus, S. (2016). Entrepreneurial orientation and SME performance across societal cultures: An international study. Journal of Business Research, 69(5), 1928-1932.

Shepherd, D. A. (2003). Learning from business failure: Propositions of grief recovery for the self-employed. Academy of Management Review, 28(2), 318-328.

Seibert, S. E., Silver, S. R., \& Randolph, W. A. (2004). Taking empowerment to the next level: A multiple-level model of empowerment, performance, and satisfaction. Academy of Management Journal, 47(3), 332349.

Simons, T., Friedman, R., Liu, L., \& Mc Lean Parks, J. (2007). Racial differences in sensitivity to behavioral integrity: Attitudinal consequences, in-group effects, and "trickle down" among black and non-black employees. Journal of Applied Psychology, 92(3), 650665.

Simons, T. L. (2002). Behavioral integrity: The perceived alignment between managers' words and deeds as a research focus. Organization Science, 13(1), 18-35.

Somech, A., \& Drach-Zahavy, A. (2013). Translating team creativity to innovation implementation: The role of team composition and climate for innovation. Journal of Management, 39(3), 684-708.

Spreitzer, G. M. (1995). Psychological empowerment in the workplace: Dimensions, measurement, and validation. Academy of Management Journal, 38(5), 1442-1465.

Sun, P. Y. T. (2013). The servant identity: Influences on the cognition and behavior of servant leaders. The Leadership Quarterly, 24(4), 544-557.

Suriyankietkaew, S., \& Avery, C. G. (2014). Employee satisfaction and sustainable leadership practices in Thai SMEs. Journal of Global Responsibility, 5(1), 160173.

Tam K. Y., \& Ho, S. Y. (2005). Web personalization as a persuasion strategy: An elaboration likelihood model perspective. Information Systems Research, 16(3), 271-291.

Tasoulis, K., Krepapa, A., \& Stewart, M. M. (2019). Leadership integrity and the role of human resource management in Greece: Gatekeeper or bystander? Thunderbird International Business Review, 61(3), 491- 503.

Thatcher, S. M., \& Patel, P. C. (2012). Group faultlines a review, integration, and guide to future research. Journal of Management, 38(4), 969-1009.

Van Dierendonck, D. (2011). Servant leadership: A review and synthesis. Journal of Management, 37(4), 12281261.

Van Knippenberg, D., De Dreu, C. K., \& Homan, A. C. (2004). Work group diversity and group performance: An integrative model and research agenda. Journal of Applied Psychology, 89(6), 1008.

Varma, T. M. (2020). Responsible leadership and reputation management during a crisis: The cases of Delta and United Airlines. Journal of Business Ethics. https:// doi.org/10.1007/s10551-020-04554-w

Vecchio, R. P. (2003). Entrepreneurship and leadership: Common trends and common threads. Human Resource Management Review, 13(2), 303-327.

Vogelgesang, G., Leroy, H., \& Avolio, B. (2013). How leader transparency impacts follower engagement: The mediating effects of behavioral integrity and participation in decision making. The Leadership Quarterly, 24(3), 405-413.

Wales, W. J., Kraus, S., Filser, M., Stöckmann, C., \& Covin, J. G. (2020). The status quo of research on entrepreneurial orientation: Conversational landmarks and theoretical scaffolding. Journal of Business Research, 128, 564-577. https://doi.org/10.1016/j.jbusres.2020.10.046

Wang, J., Zhang, Z., \& Jia, M. (2017). Understanding how leader humility enhances employee creativity: The 
roles of perspective taking and cognitive reappraisal. The Journal of Applied Behavioral Science, 53(1), 5-31.

Wei, Y. S., O'Neill, H., \& Zhou, N. J. (2020). How does perceived integrity in leadership matter to firms in a transitional economy? Journal of Business Ethics, 167(4), 623-641.

Westley, F., \& Mintzberg, H. (1989). Visionary leadership and strategic management. Strategic Management Journal, 10(S1), 17-32.

Wu, C. H., Parker, S. K., \& de Jong, J. P. J. (2014). Need for cognition as an antecedent of individual innovation behavior. Journal of Management, 40(6), 1511-1534.

Zhang, X., \& Bartol, K. M. (2010). Linking empowering leadership and employee creativity: The influence of psychological empowerment, intrinsic motivation, and creative process engagement. Academy of Management Journal, 53(1), 107-128. 